American studies, despite the great differences in characteristics of the patients. It seems relevant that the study most closely resembling ours was also a follow-up study of addicts from their first contact with treatment authorities. Close examination of Vaillant's (1966a) tables shows that over half of those classified as well at the end of the 12-year study were in this category by the second year of follow-up. He also confirmed the poor outlook of chronic addicts.

We suggest that there may be a "fail-safe" period of two to three years after which the outlook for patients is poor. The implications for treatment are twofold. Firstly, we are in agreement with Gardner and Connell (1970) and Glatt (1969) that abstinence-orientated treatment is probably most appropriate for stages 1 and 2 addicts. Secondly, as a corollary, from an experience of oral methadone extending over several years we concur with Gardner and Connell regarding the need for caution in prescribing methadone by mouth. We would not consider its use with stages 1 or 2 addicts except sometimes in the form of a short dosage-reducing course. The figures of both Bewley et al. (1972) and Boyd et al. (1971), which show a higher proportion of patients whose exact drug status could not be ascertained on short-term follow-up, are also suggestive in this context. There are two possible reasons for this change-firstly, an increasing black market in adulterated, Chinese heroin and, secondly, that stages 1 and 2 addicts may be less consistently involved with opiates, which lends weight to our suggestions for treatment. The implications of this study for a narcotic-prescribing policy, we feel, deserve further investigation.

Finally, the need for a more extensive follow-up is evident. One of the present patients relapsed to regular opiate use after being opiate-free for six years. Also, Vaillant pointed out that only $28 \%$ of his group did not use barbiturates or alcohol to excess at one time or another. O'Donnell confirmed this, and although our data are incomplete we have firm evidence of alcohol abuse (Chapple, 1972) among several of our otherwise drug-free patients. It is disturbing to reflect that our "good outcomes" may cease to be regarded as a problem only because they have become submerged in a much larger section of the community who use either oral barbiturates or alcohol or both to excess. It is possible that the larger a particular drug problem the less likely it is that its very existence will be admitted and appropriate action taken.

Acknowledgement is made to the Home Office Drugs Branch for the use of their records; they have no responsibility whatsoever for any of the conclusions. Reprints may be obtained from Dr. P. A. L. Chapple.

\section{References}

Bewley, T. H. (1965). British Medical fournal, 2, 1284

Bewley, T. H., and Ben-Arie, O. (1968). British Medical fournal, $1,727$. Bewley, T. H., et al. (1972). International Symposium on Drug Abuse,

Boyd, P., et al. (1971). British Medical Fournal, 4, 604

Chapple, P. A. L. (1972). To be published.

Chapple, P. A. L., et al. (1972). British Fournal of Addiction, 67, 33

Drugs Branch, Home Office (1970). U.K. Statistics of Drug Addiction and Criminal Offences Involving Drugs. London, Drugs Branch, Home Office.

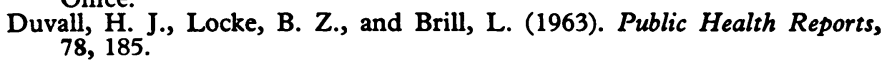

Gardner, R. (1970). Lancet, 2, 650

Gardner, R., and Connell, P. H. (1970). Lancet, 2, 455.

Glatt, M. M. (1969). British fournal of Addiction, 64, 165.

Henderson, I. (1970). An Exploration of the Natural History of Heroin Addiction. Vancouver, Narcotic Addiction Foundation of British Addiction.

Mahon, T. (1970). Doctoral Thesis, Florida State University.

Mahon, T. (1970). Doctoral Thesis, Florida State University.

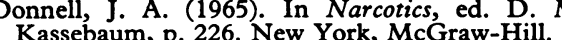

O'Donnell, J. A. (1969). Narcotic Addicts in Kentucky, Public Health Service Publication No. 1881. Washington, Public Health Service.

Vaillant, G. E. (1966a). American fournal of Psychiatry, 122, 727.

Vaillant, G. E. (1966b). New England fournal of Medicine, 275, 1282.

Vaillant, G. E. (1966c). Archives of General Psychiatry, 15, 599.

Vaillant, G. E. (1966d). American fournal of Psychiatry, 123, 573.

Winick, C. A. (1964). U.N. Bulletin on Narcotics, 18, 1.

\title{
Further Experience with Epigastric Pain Reproduction Test in Duodenal Ulceration
}

\author{
RICHARD J. EARLAM
}

British Medical fournal, 1972, 2, 683-685

\section{Summary}

Further evidence is presented that the epigastric pain of duodenal ulceration, situated between the rib margins and just below the xiphisternum, arises from the lower oesophagus.

One-hundred patients with duodenal ulceration were divided into those with epigastric pain (61) and those with pain in the upper abdomen but not in the epigastrium (39). Perfusion of $0.1 \mathrm{~N} \mathrm{HCl}$ into the lower oesophagus reproduced epigastric pain in 53 of the 61 with epigastric pain (mean $37 \mathrm{ml}$ ) but in none of the 39 without (mean $125 \mathrm{ml}$ ). All those who had been woken by epigastric pain at night in the previous four weeks had a positive test.

The London Hospital, London E.1

RICHARD J. EARLAM, M.CHIR., F.R.C.S., Consultant Surgeon
In five the test remained positive even though the acid was neutralized by a continuous perfusion of alkali just below the gastro-oesophageal junction. In another five $200 \mathrm{ml} \mathrm{O} 1 \mathrm{~N} \mathrm{HC1}$ instilled into the stomach for 21 minutes did not reproduce epigastric pain, even though $30 \mathrm{ml}$ perfused for three minutes into the lower oesophagus did.

\section{Introduction}

If weak hydrochloric acid is perfused into the lower oesophagus of patients with duodenal ulceration under accurate manometric control epigastric pain, indistinguishable from that normally suffered, can be reproduced (Earlam, 1970). When a patient had duodenal ulcer pain in sites other than the epigastrium the test was always negative. But not all those with epigastric pain had a positive test in the original study so further experiments have been evolved to establish whether epigastric pain really did arise from the lower oesophagus and why there was possibly an individual variation. The oesophageal origin of this type of pain would be likely if large amounts of intra- 
gastric acid did not cause epigastric pain and if the perfused oesophageal acid were neutralized before it could take effect on the stomach. It would also fit the previously-known fact that the oesophagus is susceptible to acid (Bernstein and Baker, 1958). This study was therefore designed to establish the reliability of the test by taking more careful note than in the previous study of when the last attack of pain occurred. It also presents further evidence to suggest that the origin of epigastric pain can be localized to the lower oesophagus.

\section{Patients and Methods}

One-hundred patients with a duodenal ulcer shown radiologically were divided into two groups on the basis of whether they had epigastric pain or not. Localization of abdominal pain was recorded on a small diagram by a doctor after the patient had pointed to the site in question with one finger on his bare skin. The definition of epigastric pain for the purpose of this study was accepted as pain between the rib margins and just below the xiphisternum in the midline. Patients who had never suffered such pain but had pain, burning, or "indigestion" in other parts of the upper abdomen were designated as the nonepigastric pain group. Altogether 61 had epigastric pain and 39 had non-epigastric pain.

All the patients were asked when they had last been woken by this pain at night. This is a normal feature of severe duodenal ulcer pain and affected both groups similarly, although the aetiological mechanism is unknown. Awakening at night must depend on the depth of sleep, gastric acid and pepsin basal secretion, and other factors but was accepted for this study as a more objective criterion of when the pain was last severe than an assessment of pain during the day, which might be related to dietary indiscretions.

Pressure measurements of the gastro-oesophageal junction were made with techniques previously described (Fyke et al., 1956). The recording units were passed through the mouth into the stomach and then withdrawn slowly at $0.5-\mathrm{cm}$ intervals to obtain the pressure profile of the gastro-oesophageal junction in its resting state. Pressures were recorded with three waterfilled, non-perfused polyethylene tubes (external diameter $1.65 \mathrm{~mm}$; internal diameter $1.12 \mathrm{~mm}$ ). The distal tube was covered with a $0.5 \mathrm{~cm}$ balloon and the two remaining tubes had lateral openings 5 and $10 \mathrm{~cm}$ from the balloon.

Lower Oesophageal Acid.-After two resting studies the balloon was accurately positioned at the sphincter by noting where relaxation and contraction occurred. Solutions were perfused through the proximal open tip $10 \mathrm{~cm}$ above the balloon at a constant rate of $8-10 \mathrm{ml} / \mathrm{min}$. If the patient had no pain immediately before the test either $0.9 \% \mathrm{NaCl}$ or 0.1 $\mathrm{N} \mathrm{HCl}$, chosen at random without the patient knowing which, was perfused until either pain was produced or $100 \mathrm{ml}$ or more had passed through the tube. Then $2 \cdot 74 \% \mathrm{NaHCO}_{3}$ was perfused until the pain disappeared. If the patient already had pain $\mathrm{NaHCO}_{3}$ was used first until relief was obtained.

Lower Oesophageal Acid and Simultaneous Intragastric Alkali.In a group of five patients simultaneous perfusion of $0.1 \mathrm{~N} \mathrm{HCl}$ above and $2.74 \% \mathrm{NaHCO}_{3}$ below the gastro-oesophageal junction was performed to eliminate any effect the acid might have on the stomach. A modified recording unit was used with three open tips and no balloon. The middle opening was positioned in the sphincter and acid was perfused through the proximal open tip $5 \mathrm{~cm}$ above and alkali through the distal open tip $5 \mathrm{~cm}$ below the sphincter. The perfusion rates of both solutions were similar at $8-10 \mathrm{ml} / \mathrm{min}$.

Lower Oesophageal Acid and Consecutive Intragastric Acid.-A further five patients had $200 \mathrm{ml} 0 \cdot 1 \mathrm{~N} \mathrm{HCl}$ instilled into the stomach for 15 to 30 minutes (after a positive epigastric pain reproduction test) in an attempt to discover whether any pain would arise from the stomach itself with a larger amount of weak acid than that put into the lower oesophagus.

\section{Results}

\section{LOWER OESOPHAGEAL ACID}

\section{Epigastric Pain Group}

Of the 100 patients with duodenal ulceration 61 suffered from epigastric pain. Of these 53 had a positive epigastric pain reproduction test and 8 did not have epigastric pain after perfusion of more than $100 \mathrm{ml} 0 \cdot 1 \mathrm{~N} \mathrm{HCl}$ (mean $128 \mathrm{ml}$ ).

The patients with this type of pain were subdivided further according to when they were last awoken at night by duodenal ulcer pain. Of the 53 with a positive test 45 had been awoken at night by epigastric pain within four weeks before the test. Five who had never been awoken at night and the remaining three who had been pain-free for three months also had a positive test. Eight of the 61 had a negative test in spite of a history of epigastric pain. Three of these had mild symptoms and had never been awoken at night and five had not been awoken by this pain within the last three months. All patients who had been awoken by epigastric pain at night in the four weeks before the test had a positive epigastric pain reproduction test.

The mean amount of $0.1 \mathrm{~N} \mathrm{HC1}$ needed to produce pain was $37 \mathrm{ml}$ and relief was obtained with $22 \mathrm{ml} 2.7 \% \mathrm{NaHCO}_{3}$. The amount of acid causing pain was usually well below $100 \mathrm{ml}$, but in three of the 53 positive tests more was needed $(112 \mathrm{ml}, 117 \mathrm{ml}$, and $125 \mathrm{ml}$ ). There was no correlation between the amount of acid needed to cause pain and the quantity of alkali needed to relieve it $(r=0 \cdot 1277)$. If a patient was awoken by pain during the night before the test the amount of acid needed to reproduce pain $(22 \mathrm{ml} \pm 21)$ was less than if the pain had occurred two to seven nights before $(50 \mathrm{ml} \pm 43, P=0.02)$. But otherwise there was no relation between the amount of acid which caused pain and when the pain last awoke the patient at night.

\section{Non-epigastric Pain Group}

None of the 39 patients without epigastric pain had a positive

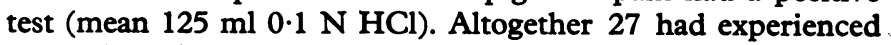
non-epigastric duodenal ulcer pain within the last four weeks, of whom 5 had been awoken the previous night, 12 during the week before the test, and 10 in the last month. Five had never been awoken by pain and five had been pain-free for more than a month. The test was not declared negative unless more than $100 \mathrm{ml}$ had been perfused.

LOWER OESOPHAGEAL ACID AND SIMULTANEOUS INTRAGASTRIC ALKALI

The epigastric pain in this group of five patients was reproduced by $22 \mathrm{ml}$ of acid and relieved by $18 \mathrm{ml}$ of $\mathrm{NaHCO}_{3}$. All had had pain at night in the previous week. The perfusion of $\mathrm{NaHCO}_{3}$ through the distal open tip below the sphincter at $10 \mathrm{ml} / \mathrm{min}$ neutralized the acid in the stomach but did not prevent acid in the lower oesophagus producing pain.

\section{LOWER OESOPHAGEAL ACID AND CONSECUTIVE INTRAGASTRIC ACID}

Five patients who had had epigastric pain during the two nights before the test had a positive pain reproduction test within three minutes of $0.1 \mathrm{~N} \mathrm{HCl}$ perfusion (mean $30 \mathrm{ml}$ ). Instillation of $200 \mathrm{ml} 0 \cdot 1 \mathrm{~N} \mathrm{HCl}$ into the stomach immediately afterwards did not cause any pain in 15 to 30 (mean 21) minutes, suggesting that although the lower oesophageal mucosa is sensitive to acid the gastric mucosa is not. 


\section{Discussion}

The first description of the epigastric pain reproduction test showed that this pain could be reproduced by weak acid in the lower oesophagus but not in every patient with a duodenal ulcer (Earlam, 1970). This study was undertaken to analyse the quantitative aspects of the test and to investigate further those in whom it was negative. It has now been shown that all patients with duodenal ulceration awoken by epigastric pain in the four weeks before the test had a positive reaction (mean $37 \mathrm{ml}$ ) and that the test must not be considered negative until at least $125 \mathrm{ml} 0 \cdot 1 \mathrm{~N} \mathrm{HCl}$ has been perfused into the lower oesophagus. The classification of epigastric pain according to when it last occurred at night is admittedly a crude method of assessing when severe pain last occurred, but it is taken as the best objective measurement of this autonomic pain available at the moment. It is not necessary for a patient to be awoken at night before having a positive pain reproduction test, so the use of night pain as the sole indication of the severity of duodenal ulcer pain is obviously limited.

The reliability of the test, when epigastric pain had been present recently, together with the further experiments to neutralize acid in the stomach and show that the gastric mucosa is insensitive to acid are considered further evidence to suggest that the epigastric pain of duodenal ulceration arises from the lower oesophagus. When night pain is used as an indication of when the pain was last severe there is no really clear correlation between pain and the amount of acid needed to reproduce it. This discrepancy could be caused by inherently different sensitivities of the lower oesophagus to this stimulus. There is, however, some evidence to suggest that patients with a duodenal ulcer but without epigastric pain have a more competent gastrooesophageal junction than those with such pain and since it would be more capable of protecting the lower oesophageal mucosa from the effects of gastric reflux (Earlam, 1971).

For a long time it has been known that the severity of duodenal ulcer symptoms does not necessarily depend on the radiological appearances of the duodenum. If the epigastric pain of duodenal ulceration arises from the lower oesophagus and not the ulcer itself some of the incongruities of these symptoms would disappear and patients could be assessed more accurately for medical or surgical treatment.

I would like to thank the physicians and surgeons in charge of these patients at The London Hospital and Mile End Hospital for permission to perform these studies and the patients themselves for their co-operation.

\section{References}

Bernstein, L. M., and Baker, L. A. (1958). Gastroenterology, 34, 760.

Earlam, R. J. (1970). British Medical fournal, 4, 714

Earlam, R. J. (1971). British fournal of Surgery, 58, 296.

Fyke, F. E., jun., Code, C. F., and Schlegel, J. F. (1956). Gastroenterologia (Basel), 86, 135.

\title{
Prospective Study of Serum Cholesterol Levels during First Year of Life*
}

\author{
JUDITH M. DARMADY， AUDREY S. FOSBROOKE， JUNE K. LLOYD
}

British Medical fournal, 1972, 2, 685-688

\section{Summary}

A longitudinal prospective study of serum cholesterol concentrations during the first year of life has been carried out in 302 healthy babies. The results show that serum cholesterol estimations in cord blood cannot be used as a screening test for the diagnosis of familial hypercholesterolaemia. The only child subsequently found to have the condition had a cord serum cholesterol of 85 $\mathrm{mg} / 100 \mathrm{ml}$ compared with the mean value for the group of $78 \mathrm{mg} / 100 \mathrm{ml}$. The babies who had cord values greater than $100 \mathrm{mg} / 100 \mathrm{ml}$ had values distributed throughout the normal range when re-examined at 1 year of age. Serum cholesterol concentrations during the early months of life were markedly influenced by the type of milk fed; it is suggested that investigations to establish the diagnosis of familial hypercholesterolaemia are deferred until the child is about 1 year old and feeding with cows' milk and mixed diet is established.

Values obtained for serum cholesterol concentrations ( $\mathrm{mg} / 100 \mathrm{ml}$, mean \pm 1 S.D.) in healthy infants in this

* Part of this work was presented at the 19th Colloquium on Protides of
the Biological Fluids (1971) and at the XIII International Congress of the Biological Fluid
Pediatrics (1971).

Department of Child Health, Institute of Child Health, London W.C.1 JUDITH M. DARMADY, M.R.C.P., Research Fellow (At present, Lecturer, Department of Child Health, University of Southampton) AUDREY S. FOSBROOKE, M.SC., Senior Lecturer JUNE K. LLOYD, M.D., F.R.C.P., Reader study were: at birth $78 \pm 23$, at 1 week $155 \pm 31$, at 6 weeks $155 \pm 31$, at 4 months $184 \pm 36$, at 8 months $195 \pm 37$, and at 1 year $191 \pm 36$.

\section{Introduction}

Familial hypercholesterolaemia (familial type II hyperlipoproteinaemia in the classification of Fredrickson et al. (1967)) is a dominantly inherited condition characterized by an increased concentration of serum betalipoprotein and cholesterol; triglyceride levels are usually normal. It is associated with an increased risk of ischaemic heart disease in early adult life (Slack, 1969). It is not yet known whether treatment that lowers serum cholesterol will prevent or delay the onset of ischaemic heart disease, but if such measures are to have maximum effect treatment should probably be started as early as possible-that is, during the childhood years. It therefore becomes important to establish the earliest age at which the diagnosis can be made.

It has been suggested that the diagnosis may be made at birth, and a few isolated cases have been reported (Lewis et al., 1967; Wolff, 1967; Lees et al., 1969) of babies who had a high cord serum cholesterol concentration (greater than $100 \mathrm{mg} / 100 \mathrm{ml}$ ) and who were subsequently shown to have familial hypercholesterolaemia. More recently two systematic studies have been reported. Kwiterovitch et al. (1970) examined the cord blood of 15 infants in whom a parent was known to have familial hypercholesterolaemia. The serum cholesterol concentration and, in particular, the betalipoprotein cholesterol were considered to be increased in seven of these babies; 8 of the 15 children were followed-up and among these one false-positive and one false-negative diagnosis have been reported. Glueck 